Sel ect i ve Separ at i on of Tri - and Pent aval ent Arseni $c$ in Aqueous Natrix with a Nacr ocycl e-I mmobi I i zed Sol i d- Phase Extract i on Syst em

\begin{tabular}{|l|l|}
\hline 著者 & $\begin{array}{l}\text { Rahnan I snai I M M, Begum Zi nnat A. , Fur usho } \\
\text { Yoshi aki, M zut ani Sat oshi, Naki Ter uya, } \\
\text { Hasegawa H r oshi }\end{array}$ \\
\hline $\begin{array}{l}\text { j our nal or } \\
\text { publ i cat i on t itl e }\end{array}$ & Wat er, Ai r and Soi I Pol I ut i on \\
\hline vol une & 224 \\
\hline number & 5 \\
\hline page r ange & $1-11$ \\
\hline year & $2013-05-01$ \\
\hline URL & ht t p: //hdl . handl e. net $/ 2297 / 34667$ \\
\hline
\end{tabular}


The research article is originally published at Water, Air, \& Soil Pollution

A Springer Journal

http://www.springer.com/environment/journal/11270

The original publication is available at: http://dx.doi.org/10.1007/s11270-013-1526-0

\section{Selective Separation of Tri- and Pentavalent Arsenic in Aqueous Matrix with a Macrocycle-Immobilized Solid Phase Extraction System}

Ismail M. M. Rahman, ${ }^{* 1,2}$ Zinnat A. Begum, ${ }^{1}$ Yoshiaki Furusho, ${ }^{3}$ Satoshi Mizutani, ${ }^{4}$ Teruya Maki ${ }^{5}$ and Hiroshi Hasegawa ${ }^{* 5}$

${ }^{1}$ Graduate School of Natural Science and Technology, Kanazawa University, Kakuma, Kanazawa 920-1192, Japan

${ }^{2}$ Department of Applied and Environmental Chemistry, University of Chittagong, Chittagong 4331, Bangladesh

${ }^{3}$ GL Sciences, Inc., Nishishinjuku 6-22-1, Shinjuku, Tokyo 163-1130, Japan

${ }^{4}$ Graduate School of Engineering, Osaka City University, Sugimoto 3-3-138, SumiyoshiKu, Osaka 558-8585, Japan

${ }^{5}$ Institute of Science and Engineering, Kanazawa University, Kakuma, Kanazawa 9201192, Japan

*Author(s) for correspondence.

E-mail: I.M.M.Rahman@gmail.com (I.M.M. Rahman); hhiroshi@t.kanazawa-u.ac.jp (H. Hasegawa).

Tel/ Fax: +81-76-234-4792

Please Cite the article as: I.M.M. Rahman, Z.A. Begum, Y. Furusho, S. Mizutani, T. Maki and H. Hasegawa, Selective separation of tri- and pentavalent arsenic in aqueous matrix with a macrocycle-immobilized solid-phase extraction system, Water, Air, \& Soil Pollution, 224(5): 1526, 2013. 


\section{Abstract}

A simple flow-based method was developed for the selective separation of arsenic species $(+3$ and +5$)$ using a macrocycle-immobilized solid phase extraction (SPE) system, commonly known as molecular recognition technology (MRT) gel. Arsenic species in solution or in the eluent were subsequently quantified with graphite furnace atomic absorption spectrometry. The separation behaviors of As(III) and As(V) on MRT-SPE were investigated. It was found that $\mathrm{As}(\mathrm{V})$ can be selectively collected on the SPE system within the range of $\mathrm{pH} 4$ to 9 , while As(III) was passed through the MRT-SPE. The retention capacity of the MRT-SPE material for $\mathrm{As}(\mathrm{V})$ was found to be $0.25 \pm 0.04 \mathrm{mmol} \mathrm{g}^{-1}$. The detection limit of the method for $\operatorname{As}(\mathrm{V})$ was $0.06 \mu \mathrm{g} \mathrm{L}^{-1}$, and the relative standard deviation was $2.9 \%(n=10, C=1 \mu \mathrm{mol}$

$\mathrm{L}^{-1}$ ). Interference from the matrix ions was studied. In order to validate the developed method, certified reference materials of effluent wastewater and groundwater samples were analyzed and the determined values were in good agreement with the certified values. The proposed method was successfully applied to the speciation analysis of tri- and pentavalent arsenic in natural water samples showing satisfactory recoveries ( $\geq 98.7 \%)$.

Keywords: Solid phase extraction; molecular recognition technology; arsenic $(+3$ and +5$)$; aqueous matrix; speciation 


\subsection{Introduction}

Arsenic has raised a major public health concern because it has serious toxic effects even at low exposure levels and is widespread in the environment (WHO 2001). People exposed to high level of arsenic via drinking water and contaminated water-irrigated foods are at risk of both cancerous and non-cancerous health effects (Karim 2000, Rahman et al. 2008). The extent of exposure depends on the concentration levels, oxidation and binding states, ionic and molecular forms and metabolic pathways of arsenic, which vary strongly in different environmental compartments (Mandal \& Suzuki 2002). Arsenite (oxidation state +3 ) and arsenate (oxidation state +5 ) are commonly found inorganic arsenic species in the natural aqueous matrix (Mandal \& Suzuki 2002, Francesconi \& Kuehnelt 2004). Information about the speciation of arsenic in the natural aqueous system is important because it indicates the bioavailability of arsenic from the source water (Liang \& Liu 2007). Inorganic arsenic species are known to be more toxic than the organic counterparts, and As(III) is at least ten times more harmful than As(V) (Squibb \& Fowler 1983). Selective and accurate measurement of arsenic species is also required for precise monitoring as imposed by increasingly stringent environmental regulations, e.g. United States Environmental Protection Agency proposed a maximum contaminant level of $10 \mu \mathrm{g} \mathrm{L^{-1 }}$ arsenic for the community water systems (USEPA 2002).

In recent years, several researchers have been working for the quantification and speciation analysis of arsenic (Barra et al. 2000, Muñoz \& Palmero 2005, Terlecka 2005, Kumar \& Riyazuddin 2007, Mays \& Hussam 2009). For the separation and detection of arsenic species, ion chromatography and high-performance liquid chromatography separation followed by sensitive detection such as inductively coupled plasma mass spectrometry (Lintschinger et al. 1998, Bissen \& Frimmel 2000), atomic absorption spectrometry with hydride generation interface (Hasegawa et al. 1999, Kumar \& Riyazuddin 
2007) and electrospray/nanospray mass spectrometry (Pergantis et al. 1997, Ritsema et al. 1998) are widely used. However, concerns related to the use of element-selective detectors to interface the chromatographic methods limit the efficiency of these techniques ( $\mathrm{Yu}$ et al. 2003). Since the 1980s, separation of analytes using solid-phase extraction (SPE) systems becomes popular. The technique is cost- and time-saving compared to the traditional extraction techniques with the facility to separate a wide range of metal ions, including specific selectivity to a particular ion (Nickson et al. 1995, Poole 2000, Rossi \& Zhang 2000, Camel 2003). SPE techniques have been applied for the quantified analysis/speciation/separation of various trace elements, including arsenic (Liska 2000, Rossi \& Zhang 2000, Yalcin \& Le 2001, Camel 2003, Yu et al. 2003, Sanchez et al. 2009, Rahman et al. 2011a, 2011b). One group of SPE material includes the macrocyclic chelants, such as crown ethers, immobilized on a silica or polymer support (Hiraoka 1982, 1992), which possess the ion-selective behavior and are commonly known as molecular recognition technology (MRT) gel (Izatt et al. 1994, Hasegawa et al. 2010, Rahman et al. 2011a, 2011b, 2011c, 2011d, Hasegawa et al. 2013).

The separation of elements by macrocycles is managed by the accommodation of ions either within their circular cavity or in the three-dimensional cavity-like structures formed between the macro-ring and the sidearms. The retention behavior depends on the relative sizes and charges of analyte ions, the conformational flexibility of the macrocycle structure, and the interaction of the macrocycle with solvent. The selectivity behavior of the macrocycle can be modified by varying any of those factors (Tsukube 1993, Mahoney et al. 2001, 2004, Nabeshima et al. 2005). Macrocycles have been employed for the selective separation of metal ions from mixtures in bulk liquid membrane and/or solvent extraction systems (Izatt et al. 1986, Walkowiak et al. 2002, Walkowiak \& Kozlowski 2009). However, separation of metal ions using extraction or membrane systems is not considered as a cost- 
effective option due to the gradual loss of the expensive macrocyclic compounds from the organic membrane or layer (Bradshaw et al. 1989). The shortcoming was minimized by attaching the macrocyclic compounds to solid support using a stable hydrocarbon-ether linkage, which is capable of high selectivity and of use with very diluted solutions (Izatt et al. 1988, Bradshaw et al. 1989, Bruening et al. 1991, Izatt et al. 1994). Silica gel is used mostly among the solid support materials due to its high hydrophilic character, large number of binding sites and substantial inert nature. Other options are adopted only when the silica gel cannot be used as the support such as when the $\mathrm{pH}$ of solution is about 10 or when extreme purification of water is required, etc. (Biernat et al. 1994, Izatt et al. 1995).

In this work, a simple process is developed for the separation of tri- and pentavalent arsenic species in the aqueous matrix with the subsequent graphite furnace atomic absorption spectrometric (GF-AAS) determination using a single MRT-SPE cartridge namely AnaLig AN-02. The proposed technique is rapid and is suitable for routine speciation analysis of inorganic arsenic in aqueous matrix to comply with the legislative recommendations in countries where the extent of contamination is severe, and a large number of samples are required to be monitored.

\subsection{Experimental}

\subsection{Instruments}

The AAnalyst 600 GF-AAS (PerkinElmer, Waltham, MA, USA) equipped with an AS 800 autosampler and a dedicated transversely-heated graphite atomizer system with Zeeman background correction facility was used as detector. The light source was an electrodeless discharge lamp (EDL) powered by EDL System II operated at $380 \mathrm{~mA}$. The wavelength was set at $193.7 \mathrm{~nm}$ resonance line and the monochromator spectral bandpass at $0.7 \mathrm{~nm}$. Baseline offset correction time was set to $2.0 \mathrm{~s}$ and the read delay at $0.0 \mathrm{~s}$. Argon was used as purge 
gas at the pre-set flow rate of $250 \mathrm{~mL} \mathrm{~min}^{-1}$. A temperature program has been performed as follows: first and second dry at 110 and $130^{\circ} \mathrm{C}$, ashing at $1200^{\circ} \mathrm{C}$ and atomization at $2000^{\circ} \mathrm{C}$ with hold times of $30,30,20$ and 5 s, respectively. The system was calibrated with fivestandards of As(III) or As(V) $\left(0.5-2.5 \mu \mathrm{mol} \mathrm{L}^{-1}\right)$. Sample $(20 \mu \mathrm{L})$ and Pd-Mg matrix modifier $(10 \mu \mathrm{L})$ solutions were introduced in the graphite furnace with three replicates of each measurement.

A GL-SPE vacuum manifold kit (for 12 samples) (GL Sciences, Tokyo, Japan) combined with an air pump (CAS-1, AS ONE, Osaka, Japan) was used for SPE. A Navi F-52 pH meter (Horiba, Kyoto, Japan) and a combination electrode were used for $\mathrm{pH}$ measurement. A fourhousing E-Pure water purification system (Barnstead/Thermolyne, Dubuque, IA, USA) was used for deionized water preparation, and the deionized water is referred to as EPW hereafter.

\subsection{Materials}

As(III) and As(V) stock solutions $\left(10 \mathrm{mmol} \mathrm{L}^{-1}\right)$ were prepared from sodium arsenite (Kanto Chemical, Tokyo, Japan) and sodium arsenate heptahydrate (Nacalai Tesque, Kyoto Japan). All chemicals were analytical-grade commercial products and used as received. Weight basis dilution with EPW was used to prepare the working standards.

MRT-SPE: AnaLig AN-02 (AN-02) (base support: silica gel, functional group: crown ether) was supplied from GL Sciences (Tokyo, Japan) and manufactured commercially by IBC Advanced Technologies (American Fork, UT, USA). Other SPE materials were (a) Chelex-100 (base support, styrene divinylbenzene; functional group, iminodiacetic acid), (b) NOBIAS Chelate PA-1 (base support, hydrophilic methacrylate; functional group, polyamino-polycarboxylic acid), (c) NOBIAS Chelate PB-1 (base support, divinylbenzene/methacrylate polymer; functional group, polyamino-polycarboxylic acid), (d) NOBIAS Ion SA-1 (base support, hydrophilic methacrylate; functional group, quaternized 
amine), and (e) NOBIAS Ion SC-1 (base support, hydrophilic methacrylate; functional group, sulfonic acid). Chelex 100 was supplied by Bio-Rad Laboratories (Hercules, CA, USA), while the other SPEs are from Hitachi High-Technologies (Tokyo, Japan). Chelex-100, NOBIAS Chelate PA-1, and NOBIAS Chelate PB-1 were the chelating resin-type SPE systems, while the NOBIAS Ion SA-1 and NOBIAS Ion SC-1 were the ion-exchange resin types. All the SPE systems were available as 3 or $5 \mathrm{~mL}$ mini-columns.

The experimental $\mathrm{pH}$ was adjusted within the range of 4 to 10 using either $\mathrm{HCl}$ or $\mathrm{NaOH}$ of $1 \mathrm{~mol} \mathrm{~L}^{-1}$ concentration. 2-( $\mathrm{N}$-morpholino)ethanesulfonic acid ( $\left.\mathrm{pH} 4-6\right)$ (Sigma-Aldrich, St. Louis, MO, USA), 2-[4-(2-hydroxyethyl)piperazin-1-yl]ethanesulfonic acid ( $\mathrm{pH}$ 7-8) (Nacalai Tesque, Kyoto, Japan), or TAPS (N-Tris(hydroxymethyl)methyl-3aminopropanesulfonic acid) ( $\mathrm{pH}$ 9-10) (MP Biomedicals, Solon, OH, USA) were used as the buffer reagent to maintain the desired $\mathrm{pH}$ as indicated in the parentheses.

To study the probable interference from coexisting ions, $\mathrm{NaCl}, \mathrm{KCl}, \mathrm{CaCl}_{2}$, and $\mathrm{MgCl}_{2}$ were used as source of cations, while $\mathrm{NaCl}, \mathrm{NaNO}_{3}$, and $\mathrm{Na}_{2} \mathrm{SO}_{4}$ were used as source of anions as purchased from Nacalai Tesque (Kyoto, Japan). Working solutions of $1 \mathrm{mmol} \mathrm{L}^{-1}$ concentration with $\mathrm{pH}$ maintained to 7 were prepared in $\mathrm{H}_{2} \mathrm{O}$ matrix followed by an equilibration period of $24 \mathrm{~h}$.

Certified reference materials (CRMs) of effluent wastewater (BCR-713) (Segura et al. 2004) and groundwater (BCR-610) (Quevauviller et al. 1998) from EC-JRC-IRMM (certified reference materials from European Commission Joint Research Centre, Institute of Reference Materials and Measurements), and spiked-samples of "real" waters: tap water (source: Kakuma campus, Kanazawa University, Kanazawa, Japan), lake water (source: Lake Biwa, Shiga, Japan), and river water (source: Asano River, Kanazawa, Japan) were analyzed using the proposed separation process. Cellulose membrane filter $(0.45 \mu \mathrm{m})$ (Advantec, Tokyo, Japan) was used to treat each of the real water samples before the analysis. 


\subsection{Cleaning}

Low-density polyethylene bottles (Nalge Nunc, Rochester, NY, USA), perfluoroalkoxy tubes and micropipette tips (Nichiryo, Tokyo, Japan) were used throughout. For cleaning, the laboratory wares were soaked in Scat 20X-PF alkaline detergent (Nacalai Tesque, Kyoto, Japan) overnight followed by rinsing with EPW, and then soaked in $4 \mathrm{~mol} \mathrm{~L}-1 \mathrm{HCl}$ overnight with subsequent rinsing using EPW.

\subsection{Separation process}

The work-flow sequence for the separation of $\mathrm{As}(\mathrm{III})$ and $\mathrm{As}(\mathrm{V})$ with $\mathrm{AN}-02$ column followed by GF-AAS determination is shown schematically in Fig. $1 . \mathrm{HNO}_{3}\left(1 \mathrm{~mol} \mathrm{~L}^{-1}, 8\right.$ $\mathrm{mL})$ and EPW (6 mL) were used for SPE column cleaning, and the desired $\mathrm{pH}$ condition (410) was maintained by allowing an appropriate buffer solution $(5 \mathrm{~mL})$ to follow through the column. After the cleaning step, $\mathrm{pH}$-adjusted sample solution $(4 \mathrm{~mL})$ was introduced into the SPE column at the pre-set flow rate of $0.2 \mathrm{~mL} \mathrm{~min}^{-1}$, and the column effluent was collected. The analyte that is not captured in the SPE column is then removed by EPW washing. The unretained concentration of analyte in the SPE system can be calculated from the total analyte concentration in the column effluent and EPW wash solution. The "captured" analyte is then eluted with $\mathrm{HNO}_{3}\left(1\right.$ and $\left.6 \mathrm{~mol} \mathrm{~L}{ }^{-1}\right)$. The arsenic concentrations in the sample solution, in the effluents and in the eluent were measured with GF-AAS.

\subsection{Results and Discussion}

\subsection{Optimization of variables}

\subsubsection{Sample loading flow rate}

Effect of sample loading flow rates, which has a reasonable impact on metal retention in SPE columns (Bag et al. 1998), adjusted in the range of 0.2 to $2 \mathrm{~mL} \mathrm{~min}^{-1}$ was checked (Fig. 2a). The retention patterns up to the flow rate of $0.25 \mathrm{~mL} \mathrm{~min}^{-1}$ were quantitative while it 
decreased with an increase of flow rates. Therefore, for the next experiments, a flow rate of

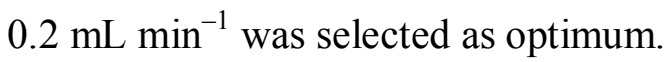

\subsubsection{Eluent concentration}

Selection of analyte is important to maintain the high enrichment factor without affecting the precise determination of analyte. The effect of eluent concentration on the elution of analyte from the MRT gel SPE column (MRT-SPE) was studied using $\mathrm{HNO}_{3}(4 \mathrm{~mL})$ of varying concentrations $\left(0.1-6 \mathrm{~mol} \mathrm{~L} \mathrm{~L}^{-1}\right)$. The recovery was quantitative up to the concentration of $0.5 \mathrm{~mol} \mathrm{~L} \mathrm{LNO}_{3}$ and then remained constant (Fig. 2b). Hence, a combination of $1 \mathrm{~mol} \mathrm{~L}^{-1} \mathrm{HNO}_{3}(2 \mathrm{~mL})+6 \mathrm{~mol} \mathrm{~L}^{-1} \mathrm{HNO}_{3}(1 \mathrm{~mL})+\mathrm{EPW}(1 \mathrm{~mL})$ was selected as eluent for the subsequent experiments.

\subsection{Separation behavior of MRT-SPE}

The separation behavior of the AN-02 column with $\mathrm{As}(\mathrm{III})$ and $\mathrm{As}(\mathrm{V})$ is illustrated in Fig. 3 in terms of $\mathrm{pH}$. The terms extraction and recovery were used to associate the retention performance of the SPE system with that of the elution. The number of moles of analyte in the elution effluent with the cumulative number of moles of the analyte present in the total effluents was compared to calculate the extraction rate. The recovery rate was calculated by comparing the number of moles of analyte recovered in all fractions with that of the number of moles of analyte in the solution loaded to the column.

Sample solutions (4 mL) spiked with $100 \mu \mathrm{mol} \mathrm{L} \mathrm{L}^{-1}$ of As(III) and As(V) were loaded to the AN-02 MRT-SPE system at a flow rate of $0.2 \mathrm{~mL} \mathrm{~min}^{-1}$. At $\mathrm{pH} 4$ to 10 , insignificant extraction was observed with As(III), while an average extraction of $97.4 \pm 4.0$ was observed for $\mathrm{As}(\mathrm{V})$ until $\mathrm{pH}$ 9. Factors such as $\mathrm{p} K_{\mathrm{a}}$ values, ionic characters of the arsenic species, and hydrophobic interaction between the arsenic species and the SPE materials may have a significant effect on the retention efficiency of the SPE columns (Yu et al. 2003). The 
distribution of different arsenic species in terms of $\mathrm{pH}$ in the aqueous medium can be determined from the respective $\mathrm{p} K_{\mathrm{a}}$ values of $\mathrm{As}(\mathrm{III})\left(\mathrm{p} K_{\mathrm{a} 1}=9.2, \mathrm{p} K_{\mathrm{a} 2}=12.2, \mathrm{p} K_{\mathrm{a} 3}=13.4\right)$ and $\operatorname{As}(\mathrm{V})\left(\mathrm{p} K_{\mathrm{a} 1}=2.2, \mathrm{p} K_{\mathrm{a} 2}=6.9, \mathrm{p} K_{\mathrm{a} 3}=11.5\right)$, and it has been confirmed that As(III) exists mostly as a neutral species $\left(\mathrm{H}_{3} \mathrm{AsO}_{3}\right)$ and $\mathrm{As}(\mathrm{V})$ as an anionic species $\left(\mathrm{H}_{2} \mathrm{AsO}^{4-}, \mathrm{HAsO}_{4}{ }^{2-}\right)$ within the studied pH range (Chen et al. 2009). The macrocycle immobilized in AN-02 MRTSPE system is designed for anion separation (Anonymous 2005), and therefore the observed behavior was expected.

The extraction and recovery behavior shows that AN-02 MRT-SPE system can selectively separate $\mathrm{As}(\mathrm{III})$ and $\mathrm{As}(\mathrm{V})$ at varying $\mathrm{pH}$ conditions ( $\mathrm{pH}$ 4-9), i.e., the separation process is almost $\mathrm{pH}$ independent and is useful for the quantitative determination of As(III) and $\mathrm{As}(\mathrm{V})$ content in the sample water. The recovery rate with AN-02 SPE column for all the arsenic species at the entire studied $\mathrm{pH}$ range was quantitative while a certain decrease in the extraction rate was observed above $\mathrm{pH}$ 9. The deviation is attributable to the increasing dissolving tendency of the silica gel base support with increasing $\mathrm{pH}$ (Vogelsberger et al. 1992).

\subsection{Effect of matrix ions}

The likely interfering effect from the matrix co-component ions on the As(V) separation efficiency with the AN-02 MRT-SPE system was examined at the following conditions: matrix $-\mathrm{H}_{2} \mathrm{O}, \mathrm{pH}-7$, sample volume- $4 \mathrm{~mL}$, flow rate- $-0.2 \mathrm{~mL} \mathrm{~min}{ }^{-1}$, elution- $1 \mathrm{~mol} \mathrm{~L}^{-1} \mathrm{HNO}_{3}$ $(2 \mathrm{~mL})+6 \mathrm{~mol} \mathrm{~L}^{-1} \mathrm{HNO}_{3}(1 \mathrm{~mL})+\mathrm{EPW}(1 \mathrm{~mL})$. The binary mixtures containing the $1 \mathrm{mmol}$ $\mathrm{L}^{-1}$ of $\mathrm{Na}^{+}, \mathrm{K}^{+}, \mathrm{Ca}^{2+}, \mathrm{Mg}^{2+} \mathrm{Cl}^{-}, \mathrm{NO}_{3}{ }^{-}$, or $\mathrm{SO}_{4}{ }^{2-}$ and $10 \mu \mathrm{mol} \mathrm{L}{ }^{-1}$ of $\mathrm{As}(\mathrm{V})$ were individually loaded to the MRT-SPE system. The rate of recovery was in the range of $92.1 \pm 1.8$ to $96.2 \pm 3.7 \%$, which can be termed as quantitative. Therefore, it can be assumed that the deterring impact due to the ions commonly found in natural water on the separation of $\mathrm{As}(\mathrm{V})$ with the AN-02 MRT-SPE is negligible. 


\subsection{Retention capacity of the MRT-SPE}

Retention capacity of the MRT-SPE system, an important property for determining the stability of the SPE column during the separation process, was computed from the analyte concentration and breakthrough volume-the volume of sample that causes the target analyte to be eluted from the SPE columns (Yu et al. 2003). As(V)-fortified sample solution prepared in $\mathrm{H}_{2} \mathrm{O}$ matrix was fed to the SPE column at a flow rate of $0.2 \mathrm{~mL} \mathrm{~min}^{-1}$ and then eluted with $2 \mathrm{~mL}$ of $1 \mathrm{~mol} \mathrm{~L}^{-1} \mathrm{HNO}_{3}+1 \mathrm{~mL}$ of $6 \mathrm{~mol} \mathrm{~L}^{-1} \mathrm{HNO}_{3}+1 \mathrm{~mL}$ of EPW. The retention capacity of the AN-02 column at $\mathrm{pH} 7$ was calculated as $0.25 \pm 0.04 \mathrm{mmol} \mathrm{g}^{-1}$.

\subsection{Reusability of the MRT-SPE}

The reusability of the AN-02 MRT-SPE was investigated with the sample solution spiked with $100 \mu \mathrm{mol} \mathrm{L} \mathrm{L}^{-1}$ of $\mathrm{As}(\mathrm{V})$ ions in the aqueous matrix (flow rate- $0.2 \mathrm{~mL} \mathrm{~min}{ }^{-1}$, elution-2 $\mathrm{mL}$ of $1 \mathrm{~mol} \mathrm{~L}^{-1} \mathrm{HNO}_{3}+1 \mathrm{~mL}$ of $6 \mathrm{~mol} \mathrm{~L}^{-1} \mathrm{HNO}_{3}+1 \mathrm{~mL}$ of EPW; $\left.n=3\right)$. As(V) extraction rate $(\%)$ of the fresh SPE column at $\mathrm{pH} 7$ was $100 \pm 3.4$, while it was $98.3 \pm 4.2$ after 100 cycles. Hence, AN-02 column can be regenerated for more than 100 loading and elution cycles without the loss of analytical performance. The regeneration process for MRT-SPE is also simple because As(III) remain in the column effluent while As(V) eluted completely. SPE systems with macrocycles attached onto solid supports offer the option of selective separation of analytes from the matrix with the advantage of repeated use of the macrocycles (Bradshaw et al. 1988, Horwitz et al. 1992, Izatt 1997). Such opportunity of regeneration could facilitate the amortization of the initial high cost of material synthesis.

\subsection{Analytical characteristics}

The calibration graphs obtained at the optimized conditions showed linear patterns up to at least $2.5 \mu \mathrm{mol} \mathrm{L}{ }^{-1}$ with the respective correlation coefficients of 0.9981 and 0.9914 . The precision at $1 \mu \mathrm{mol} \mathrm{L} \mathrm{L}^{-1}$ of $\mathrm{As}(\mathrm{III})$ and $\mathrm{As}(\mathrm{V})$ concentrations were 0.7 and $2.9 \%$ relative 
standard deviations $(n=10)$. The value of the limit of detection, calculated by three times the standard deviation of the blank $(n=15)$, were $0.06 \mu \mathrm{g} \mathrm{L}^{-1}$ for As(III) and As(V).

\subsection{Comparative performance of MRT-SPE and other commercial SPE materials}

Aqueous solutions containing $100 \mu \mathrm{mol} \mathrm{L}{ }^{-1}$ of As(V) were treated with AN-02 MRT-SPE and other commercial SPE materials (Chelex-100, NOBIAS Chelate PA-1, NOBIAS Chelate PB-1, NOBIAS Ion SA-1, NOBIAS Ion SC-1) to compare the separation efficiencies at optimized conditions. As shown in Fig. 4, MRT-SPE demonstrates quantitative separation efficiency from fortified aqueous solutions, while the recovery rate achieved for other SPE systems is $\leq 80 \%$. The MRT-SPE types contain macrocyclic chelants, such as crown ethers, immobilized on the solid-phase (Izatt et al. 1994, Bradshaw \& Izatt 1997). The crown ethers possess excellent structural diversity and superior selectivity properties among all the parent macrocycles (Tsukube 1993), and this might be associated to the greater retention performance with the MRT-SPE than the traditional ion-exchange or chelating resin-type SPE systems.

A comparison of the proposed technique for the selective separation of $\mathrm{As}(\mathrm{III})$ and $\mathrm{As}(\mathrm{V})$ in aqueous matrix using MRT-SPE with the other SPE-coupled options, as reported in the literature, is listed in Table 1 . The recovery rate (\%) of the target analyte, method detection

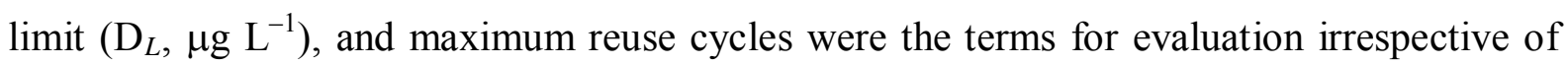
the instrumental method used for analysis. The $\mathrm{As}(\mathrm{V})$ recovery rate $(\%)$ from the AN-02 MRT-SPE was analogous to the other appraised techniques. A better $\mathrm{D}_{L}$ was reported for LCSAX (Yalcin \& Le 2001) or silica/AAPTS (Chen et al. 2009) coupled separation techniques, while the reuse sustainability of those SPE systems was either lower or not available for comparison. The technique with the ion-exchange resin Dowex 1-X8 $\left(\mathrm{Cl}^{-}\right.$form) (Smichowski et al. 2002) has better method detection limit and can sustain for the same number of reuse cycles as compared to the proposed AN-02 MRT-SPE option. The advantage of the MRT- 
SPE types than the ion-exchange resin types is the selectivity in the separation via "hostguest" complexation, which occur only when the host (usually a macrocycle that is tailored to the target based on charge, size, and shape) recognizes the specific electronic and spatial features of the guest (Izatt et al. 1995). The MRT-SPE materials have a greater concentration of active sites compared to the conventional option for separation of ions in solid phase due to the attachment of the enmeshed small microporous particles into the microfibrous matrix. The aforesaid approach also eliminates the channeling effect that recurrently appeared with packed bed SPE processes (Goken et al. 1994, Izatt et al. 1995).

\subsection{Accuracy and applications}

\subsubsection{Evaluation using certified reference materials}

The accuracy of the proposed method was evaluated by analyzing two EC-JRC-IRMM CRMs: effluent wastewater (BCR-713) and groundwater (BCR-610). Total arsenic contents in the CRMs were in good agreement with the certified values (Table 2).

\subsubsection{Analysis of natural water samples}

The proposed separation process was applied to the analysis of natural water samples (tap water, lake water, and river water) collected from local sources. The samples were spiked with known amounts of As(III) and As(V). Analytical results for the natural waters are given in Table 3, and almost quantitative recoveries were obtained in all cases.

\subsection{Conclusion}

Selective determination with GF-AAS after selective separation of As(III) and As(V) with a single MRT-SPE column: AnaLig AN-02 was achieved. As(V) was completely retained and recovered from the MRT-SPE system within the $\mathrm{pH}$ of 4 to 9 , while As(III) remained in the column effluent. At a flow rate of $0.2 \mathrm{~mL} \min ^{-1}$, the following elution combination was used: $1 \mathrm{~mol} \mathrm{~L}^{-1} \mathrm{HNO}_{3}(2 \mathrm{~mL})+6 \mathrm{~mol} \mathrm{~L}^{-1} \mathrm{HNO}_{3}(1 \mathrm{~mL})+\mathrm{EPW}(1 \mathrm{~mL})$ to 
recover the "captured" species from the MRT gel structure. The process offers a single-step separation option of trivalent and pentavalent arsenic species that commonly exist in the natural aqueous matrix. Easy operation, rapid separation performance, and reusability for more than 100 cycles without loss of the analytical performance of the MRT-SPE are some additional characteristics of the proposed process which make it a suitable and economic option for, particularly, the arsenic-prone nations suffering from natural arsenic contamination.

\section{Acknowledgements}

This research was partially supported by the Grants-in-Aid for Scientific Research (24310056 and 24·02029) from the Japan Society for the Promotion of Science. 


\section{References}

Anonymous (2005). AnaLig® Data Sheet: AN-02. IBC Advanced Technologies, Inc., American Fork, UT.

Bag, H., Lale, M. \& Türker, A. R. (1998). Determination of iron and nickel by flame atomic absorption spectrophotometry after preconcentration on Saccharomyces cerevisiae immobilized sepiolite. Talanta, 47, 689-696.

Barra, C. M., Santelli, R. E., Abrão, J. J. \& Guardia, M. d. 1. (2000). Arsenic speciation - A review. Quimica Nova, 23, 58-70.

Biernat, J. F., Konieczka, P., Tarbet, B. J., Bradshaw, J. S. \& Izatt, R. M. (1994). Complexing and chelating agents immobilized on silica gel and related materials and their application for sorption of inorganic species. Separation and Purification Methods, 23, 77-348.

Bissen, M. \& Frimmel, F. H. (2000). Speciation of As(III), As(V), MMA and DMA in contaminated soil extracts by HPLC-ICP/MS. Fresenius Journal of Analytical Chemistry, 367, 51-55.

Bradshaw, J. S., Bruening, R. L., Krakowiak, K. E., Tarbet, B. J., Bruening, M. L., Izatt, R. M. \& Christensen, J. J. (1988). Preparation of silica gel-bound macrocycles and their cation-binding properties. Journal of the Chemical Society-Chemical Communications, 812-814.

Bradshaw, J. S. \& Izatt, R. M. (1997). Crown ethers: The search for selective ion ligating agents. Accounts of Chemical Research, 30, 338-345.

Bradshaw, J. S., Izatt, R. M., Christensen, J. J., Krakowiak, K. E., Tarbet, B. J., Bruening, R. L. \& Lifson, S. (1989). Stable silica gel-bound crown ethers. Selective separation of metal ions and a potential for separations of amine enantiomers. Journal of Inclusion Phenomena and Macrocyclic Chemistry, 7, 127-136.

Bruening, M. L., Mitchell, D. M., Bradshaw, J. S., Izatt, R. M. \& Bruening, R. L. (1991). Effect of organic solvent and anion type on cation binding constants with silica gel bound macrocycles and their use in designing selective concentrator columns. Analytical Chemistry, 63, 21-24.

Camel, V. (2003). Solid phase extraction of trace elements. Spectrochimica Acta Part BAtomic Spectroscopy, 58, 1177-1233.

Chen, D., Huang, C., He, M. \& Hu, B. (2009). Separation and preconcentration of inorganic arsenic species in natural water samples with 3-(2-aminoethylamino) 
propyltrimethoxysilane modified ordered mesoporous silica micro-column and their determination by inductively coupled plasma optical emission spectrometry. Journal of Hazardous Materials, 164, 1146-1151.

Francesconi, K. A. \& Kuehnelt, D. (2004). Determination of arsenic species: A critical review of methods and applications, 2000-2003. Analyst, 129, 373-395.

Goken, G., Bruening, R. \& Bray, L. (1994) Solid phase extraction membranes for selective radionuclide separation. AIChE Summer National Meeting. Denver, CO.

Hasegawa, H., Matsui, M., Okamura, S., Hojo, M., Iwasaki, N. \& Sohrin, Y. (1999). Arsenic speciation including 'hidden' arsenic in natural waters. Applied Organometallic Chemistry, 13, 113-119.

Hasegawa, H., Rahman, I. M. M., Begum, Z. A., Umehara, Y., Maki, T., Furusho, Y. \& Mizutani, S. (2013). A silica gel-bound macrocycle system for the selective separation of toxic cadmium from metal-affluent aqueous matrix. Central European Journal of Chemistry, 11, 341-347.

Hasegawa, H., Rahman, I. M. M., Kinoshita, S., Maki, T. \& Furusho, Y. (2010). Nondestructive separation of metal ions from wastewater containing excess aminopolycarboxylate chelant in solution with an ion-selective immobilized macrocyclic material. Chemosphere, 79, 193-198.

Hiraoka, M. (1982). Crown Compounds: Their Characteristics and Applications. Amsterdam: Elsevier.

Hiraoka, M. (1992). Crown Ethers and Analogous Compounds. Amsterdam: Elsevier.

Horwitz, E., Dietz, M. \& Chiarizia, R. (1992). The application of novel extraction chromatographic materials to the characterization of radioactive waste solutions. Journal of Radioanalytical and Nuclear Chemistry, 161, 575-583.

Izatt, R. M. (1997). Review of selective ion separations at BYU using liquid membrane and solid phase extraction procedures. Journal of Inclusion Phenomena and Macrocyclic Chemistry, 29, 197-220.

Izatt, R. M., Bradshaw, J. S., Bruening, R. L. \& Bruening, M. L. (1994). Solid phase extraction of ions of analytical interest using molecular recognition technology. American Laboratory, 26, 28C-28M

Izatt, R. M., Bradshaw, J. S., Bruening, R. L., Tarbet, B. J. \& Bruening, M. L. (1995). Solid phase extraction of ions using molecular recognition technology. Pure and Applied Chemistry, 67, 1069-1074. 
Izatt, R. M., Bruening, R. L., Bruening, M. L., Tarbet, B. J., Krakowiak, K. E., Bradshaw, J. S. \& Christensen, J. J. (1988). Removal and separation of metal ions from aqueous solutions using a silica-gel-bonded macrocycle system. Analytical Chemistry, 60, 18251826.

Izatt, R. M., Clark, G. A., Bradshaw, J. S., Lamb, J. D. \& Christensen, J. J. (1986). Macrocycle-facilitated transport of ions in liquid membrane systems. Separation and Purification Methods, 15, 21-72.

Karim, M. (2000). Arsenic in groundwater and health problems in Bangladesh. Water Research, 34, 304-310.

Kumar, A. R. \& Riyazuddin, P. (2007). Non-chromatographic hydride generation atomic spectrometric techniques for the speciation analysis of arsenic, antimony, selenium, and tellurium in water samples - A review. International Journal of Environmental Analytical Chemistry, 87, 469-500.

Liang, P. \& Liu, R. (2007). Speciation analysis of inorganic arsenic in water samples by immobilized nanometer titanium dioxide separation and graphite furnace atomic absorption spectrometric determination. Analytica Chimica Acta, 602, 32-36.

Lintschinger, J., Schramel, P., Hatalak-Rauscher, A., Wendler, I. \& Michalke, B. (1998). A new method for the analysis of arsenic species in urine by using HPLC-ICP-MS. Fresenius Journal of Analytical Chemistry, 362, 313-318.

Liska, I. (2000). Fifty years of solid-phase extraction in water analysis - Historical development and overview. Journal of Chromatography A, 885, 3-16.

Mahoney, J. M., Beatty, A. M. \& Smith, B. D. (2001). Selective recognition of an alkali halide contact ion-pair. Journal of the American Chemical Society, 123, 5847-5848.

Mahoney, J. M., Beatty, A. M. \& Smith, B. D. (2004). Selective solid-liquid extraction of lithium halide salts using a ditopic macrobicyclic receptor. Inorganic Chemistry, 43, $7617-7621$.

Mandal, B. K. \& Suzuki, K. T. (2002). Arsenic round the world: A review. Talanta, 58, 201235.

Mays, D. E. \& Hussam, A. (2009). Voltammetric methods for determination and speciation of inorganic arsenic in the environment - A review. Analytica Chimica Acta, 646, 6-16.

Muñoz, E. \& Palmero, S. (2005). Analysis and speciation of arsenic by stripping potentiometry: A review. Talanta, 65, 613-620. 
Nabeshima, T., Saiki, T., Iwabuchi, J. \& Akine, S. (2005). Stepwise and dramatic enhancement of anion recognition with a triple-site receptor based on the calix[4]arene framework using two different cationic effectors. Journal of the American Chemical Society, 127, 5507-5511.

Nickson, R. A., Hill, S. J. \& Worsfold, P. J. (1995). Analytical perspective. Solid phase techniques for the preconcentration of trace metals from natural waters. Analytical Proceedings including Analytical Communications, 32, 387-395.

Pergantis, S. A., Winnik, W. \& Betowski, D. (1997). Determination of ten organoarsenic compounds using microbore high-performance liquid chromatography coupled with electrospray mass spectrometry mass spectrometry. Journal of Analytical Atomic Spectrometry, 12, 531-536.

Poole, C. F. (2000). Solid-phase extraction. In D. W. Ian (ed.), Encyclopedia of Separation Science. Oxford: Academic Press.

Quevauviller, P., Andersen, K., Merry, J. \& Jagt, H. V. D. (1998). The Certification of the Contents (Mass Fractions) of Aluminium, Arsenic, Cadmium, Copper and Lead in Groundwater (Low Content CRM 609; High Content CRM 610). Luxembourg: Institute for Reference Materials and Measurements, European Commission.

Rahman, I. M. M., Begum, Z. A. \& Hasegawa, H. (2011a). Application of Molecular Recognition Technology: For Selective Solid Phase Extraction of Ions. Saarbrücken, Germany: LAP LAMBERT Academic Publishing.

Rahman, I. M. M., Begum, Z. A., Nakano, M., Furusho, Y., Maki, T. \& Hasegawa, H. (2011b). Selective separation of arsenic species from aqueous solutions with immobilized macrocyclic material containing solid phase extraction columns. Chemosphere, 82, 549-556.

Rahman, I. M. M., Furusho, Y., Begum, Z. A., Izatt, N., Bruening, R., Sabarudin, A. \& Hasegawa, H. (2011c). Separation of lead from high matrix electroless nickel plating waste solution using an ion-selective immobilized macrocycle system. Microchemical Journal, 98, 103-108.

Rahman, I. M. M., Furusho, Y., Begum, Z. A., Sabarudin, A., Motomizu, S., Maki, T. \& Hasegawa, H. (2011d). Selective separation of some ecotoxic transition metal ions from aqueous solutions using immobilized macrocyclic material containing solid phase extraction system. Central European Journal of Chemistry, 9, 1019-1026. 
Rahman, I. M. M., Nazim Uddin, M., Hasan, M. T. \& Hossain, M. M. (2008). Assimilation of arsenic into edible plants grown in soil irrigated with contaminated groundwater. In J. Bundschuh, M. A. Armienta, P. Birkle, P. Bhattacharya, J. Matschullat \& A. B. Mukherjee (eds.), Natural Arsenic in Groundwaters of Latin America. Leiden, The Netherlands: CRC Press/Balkema.

Ritsema, R., Dukan, L., Navarro, T. R. I., van Leeuwen, W., Oliveira, N., Wolfs, P. \& Lebret, E. (1998). Speciation of arsenic compounds in urine by LC-ICP MS. Applied Organometallic Chemistry, 12, 591-599.

Rossi, D. T. \& Zhang, N. (2000). Automating solid-phase extraction: Current aspects and future prospects. Journal of Chromatography A, 885, 97-113.

Sanchez, W. M., Zwicker, B. \& Chatt, A. (2009). Determination of As(III), As(V), MMA and DMA in drinking water by solid phase extraction and neutron activation. Journal of Radioanalytical and Nuclear Chemistry, 282, 133-138.

Segura, M., Madrid, Y., Cámara, C., Rebollo, C., Azcarate, J., Kramer, G. N., Gawlik, B. M., Lamberty, A., Quevauviller, P. \& Bowadt, S. (2004). The Certification of the Mass Concentrations of As, Cd, Cr, Cu, Fe, Mn, Ni, Pb, Se and $\mathrm{Zn}$ in Wastewater, BCR-713 (Effluent Wastewater), BCR-714 (Influent Wastewater) BCR-715 (Industrial Effluent Wastewater). Luxembourg: Institute for Reference Materials and Measurements, European Commission.

Smichowski, P., Valiente, L. \& Ledesma, A. (2002). Simple method for the selective determination of $\operatorname{As}(\mathrm{III})$ and $\mathrm{As}(\mathrm{V})$ by ETAAS after separation with anion exchange mini-column. Atomic Spectroscopy, 23, 92-97.

Squibb, K. S. \& Fowler, B. A. (1983). The toxicity of arsenic and its compounds. In B. A. Fowler (ed.), Biological and Environmental Effects of Arsenic. New York: Elsevier Science Publishers B.V.

Terlecka, E. (2005). Arsenic speciation analysis in water samples: A review of the hyphenated techniques. Environmental Monitoring and Assessment, 107, 259-284.

Tsukube, H. (1993). Double armed crown ethers and armed macrocycles as a new series of metal-selective reagents: A review. Talanta, 40, 1313-1324.

USEPA (2002). Implementation Guidance for the Arsenic Rule - Drinking Water Regulations for Arsenic and Clarifications to Compliance and New Source Contaminants Monitoring (EPA-816-K-02-018). Washington, DC: United States Environmental Protection Agency (USEPA). 
Vogelsberger, W., Seidel, A. \& Rudakoff, G. (1992). Solubility of silica gel in water. Journal of the Chemical Society-Faraday Transactions, 88, 473-476.

Walkowiak, W. \& Kozlowski, C. A. (2009). Macrocycle carriers for separation of metal ions in liquid membrane processes - A review. Desalination, 240, 186-197.

Walkowiak, W., Ulewicz, M. \& Kozłowski, C. (2002). Application of macrocycle compounds for metal ions separation and removal - A review. Ars Separatoria Acta, 1, 87-98.

WHO (2001). Environmental Health Criteria 224: Arsenic and Arsenic Compounds Geneva: World Health Organization (WHO).

Xiong, C., He, M. \& Hu, B. (2008). On-line separation and preconcentration of inorganic arsenic and selenium species in natural water samples with CTAB-modified alkyl silica microcolumn and determination by inductively coupled plasma-optical emission spectrometry. Talanta, 76, 772-779.

Yalcin, S. \& Le, X. C. (2001). Speciation of arsenic using solid phase extraction cartridges. Journal of Environmental Monitoring, 3, 81-85.

Yu, C. H., Cai, Q. T., Guo, Z. X., Yang, Z. G. \& Khoo, S. B. (2003). Inductively coupled plasma mass spectrometry study of the retention behavior of arsenic species on various solid phase extraction cartridges and its application in arsenic speciation. Spectrochimica Acta Part B-Atomic Spectroscopy, 58, 1335-1349. 
Water, Air, \& Soil Pollution, 224(5): 1526, 2013.

The original publication is available at: http://dx.doi.org/10.1007/s11270-013-1526-0

1 Table 1. Comparison of the proposed technique with the AN-02 MRT-SPE for selective separation of tri- and pentavalent arsenic, and the other

2 SPE-coupled options

\begin{tabular}{|c|c|c|c|c|c|c|c|c|}
\hline SPE-system & Sample & $\mathbf{p H}$ & Eluent & Detector & $\boldsymbol{R}$ & $D_{\mathrm{L}}$ & $\boldsymbol{R}_{\mathrm{c}}$ & Ref. \\
\hline AnaLig AN-02 ${ }^{a}$ & $\begin{array}{l}\text { Tap, lake, and river water, } \\
\text { CRM BCR-713 and BCR-610 }\end{array}$ & $4-9$ & $\begin{array}{l}1 \text { and } 6 \mathrm{~mol} \\
\mathrm{~L}^{-1} \mathrm{HNO}_{3}\end{array}$ & GF-AAS & $98.7-101$ & 0.06 & 100 & This work \\
\hline Silica/AAPTS $^{\text {a }}$ & $\begin{array}{l}\text { Lake and well water, } \\
\text { GSBZ50004-88 }\end{array}$ & $3-9$ & $\begin{array}{l}1 \mathrm{~mol} \mathrm{~L}^{-1} \\
\mathrm{HCl}\end{array}$ & ICP-OES & $91-108$ & 0.05 & 50 & Chen et al. (2009) \\
\hline Extract-Clean SPE SAX ${ }^{\mathrm{a}}$ & CRM EP-H-1 and EP-L-1 ${ }^{b}$ & 6.5 & $\begin{array}{l}1 \mathrm{~mol} \mathrm{~L}^{-1} \\
\mathrm{HNO}_{3}\end{array}$ & NAA & - & 1.7 & - & Sanchez et al. (2009) \\
\hline CTAB/Silica ${ }^{\text {a }}$ & $\begin{array}{l}\text { River, lake, well, rain, pool and } \\
\text { tap water, ERM BW3209 } \\
(0602) \text { and BW3210 (0602) }\end{array}$ & 6.5 & $\begin{array}{l}1 \mathrm{~mol} \mathrm{~L}^{-1} \\
\mathrm{HNO}_{3}\end{array}$ & ICP-OES & $93-106$ & 0.15 & 15 & Xiong et al. (2008) \\
\hline Dowex $1-X 8^{a}$ & Tap, lake, and well water & 7 & $\begin{array}{l}0.8 \mathrm{~mol} \mathrm{~L}^{-1} \\
\mathrm{HCl}\end{array}$ & GF-AAS & $92-106$ & 0.004 & 100 & Smichowski et al. (2002) \\
\hline LC-SAX ${ }^{a}$ & $\begin{array}{l}\text { River and tap water; Urine; } \\
\text { NIST-SRM } 2670^{\mathrm{b}}\end{array}$ & Acidic & $\begin{array}{l}1 \mathrm{~mol} \mathrm{~L}^{-1} \\
\mathrm{HCl}\end{array}$ & FI-HGAFS & $\sim 100$ & 0.05 & - & Yalcin and Le (2001) \\
\hline
\end{tabular}

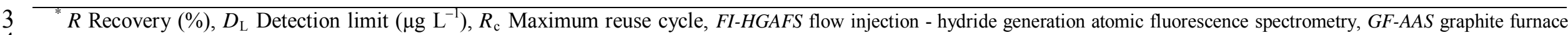
atomic absorption spectrometry, ICP-OES inductively coupled plasma optical emission spectrometry, NAA neutron activation analysis.

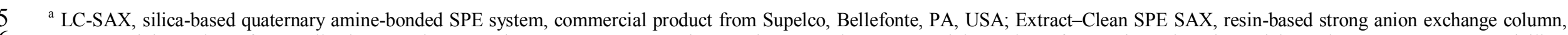
commercial product from Alltech, Ontario, Canada; Dowex 1-X8, anion exchange resin, commercial product from Bio-Rad Labs, Richmond, CA, USA; CTAB/Silica, cetyltrimethylammonium bromide (CTAB)-modified alkyl silica sobent; silica/AAPTS, 3-(2-aminoethylamino) propyltrimethoxysilane (AAPTS) modified ordered mesoporous silica; AnaLig AN-02, Immobilized macrocyclic material containing SPE system, commercial product from IBC Advanced Technologies, Inc., Utah, USA

${ }^{b}$ NIST-SRM 2670, toxic metals in urine [NIST-SRM: standard reference material from National Institute of Standards and Technology (NIST, Gaithersburg, MD, USA)]; CRM EP-H-1(highlevel concentrate) and EP-L-1 (low-level concentrate), drinking water certified reference materials (SCP Science, Canada); ERM BW3209 (0602) and ERM BW3210 (0602), environmental water samples complying National standard of the People's Republic of China [ERM: Environmental reference materials from Institute of Reference Materials, SEPA Beijing, P.R. China]; GSBZ50004-88, certified reference material of environmental water [Institute for Environmental Reference Materials, Ministry of Environmental Protection of China, Beijing, China); CRM BCR-713 (effluent wastewater) and BCR-610 (groundwater), certified reference materials from EC-JRC-IRMM (European Commission Joint Research Centre, Institute of Reference Materials and Measurements) 
Table 2. Evaluation of the tri- and pentavalent arsenic separation performance of the AN-02 MRT-SPE with the EC-JRC-IRMM CRMs

\begin{tabular}{|c|c|c|c|c|}
\hline \multirow[t]{3}{*}{ Arsenic species } & \multirow{2}{*}{\multicolumn{2}{|c|}{$\begin{array}{l}\text { Effluent wastewater CRM } \\
\text { BCR-713 }\left(\mu \mathrm{g} \mathrm{L}^{-1}\right)^{\mathrm{a}}\end{array}$}} & \multirow{2}{*}{\multicolumn{2}{|c|}{$\begin{array}{l}\text { Groundwater CRM } \\
\text { BCR-610 }\left(\mu \mathrm{g} \mathrm{L}^{-1}\right)^{\mathrm{b}}\end{array}$}} \\
\hline & & & & \\
\hline & This work & Certified value $^{\mathrm{c}}$ & This work & Certified value $^{\mathrm{c}}$ \\
\hline As(III) & $1.9 \pm 0.3$ & NR & $3.3 \pm 0.6$ & NR \\
\hline $\mathrm{As}(\mathrm{V})$ & $7.1 \pm 1.2$ & NR & $6.9 \pm 1.1$ & NR \\
\hline$\sum$ (As-species) & $9.0 \pm 1.4$ & $9.7 \pm 1.1$ & $10.2 \pm 1.6$ & $10.8 \pm 0.4$ \\
\hline
\end{tabular}

$\overline{{ }^{a}}$ BCR-713 is an effluent wastewater reference material certified by BCR (Community Bureau of Reference, the former reference materials programme of the European Commission) and available from the EC-JRC-IRMM (European Commission Joint Research Centre, Institute of Reference Materials and Measurements) (Segura et al. 2004).

${ }^{\mathrm{b}}$ BCR-610 is a groundwater reference material certified by BCR (Community Bureau of Reference, the former reference materials programme of the European Commission) and available from the EC-JRC-IRMM (European Commission Joint Research Centre, Institute of Reference Materials and Measurements) (Quevauviller et al. 1998).

${ }^{\mathrm{c}}$ BCR-713 and BCR-610 are certified for total contents of different metal ions in the samples following collaboratively tested and harmonized procedures (Quevauviller et al. 1998, Segura et al. 2004). The mentioned certified value is for total arsenic contents in the samples while the term "NR" stands for "Not reported" 
Table 3. The tri- and pentavalent arsenic content analysis in the natural water samples after the AN-02 MRT-SPE separation

\begin{tabular}{|c|c|c|c|c|c|c|}
\hline Sample & As(III) & & & $\overline{\mathrm{As}}(\mathrm{V})$ & & \\
\hline \multirow{3}{*}{ Tap water } & Added $\left(\mu \mathrm{g} \mathrm{L}^{-1}\right)$ & 0 & 19.5 & Added $\left(\mu \mathrm{g} \mathrm{L}^{-1}\right)$ & 0 & 31.2 \\
\hline & Found $\left(\mu \mathrm{g} \mathrm{L}^{-1}\right)$ & $\mathrm{BDL}^{\mathrm{a}}$ & $19.4 \pm 0.1$ & Found $\left(\mu \mathrm{g} \mathrm{L}^{-1}\right)$ & $\mathrm{BDL}^{\mathrm{a}}$ & $31.5 \pm 0.3$ \\
\hline & Recovery (\%) & - & $99.5 \pm 0.6$ & Recovery (\%) & - & $100.9 \pm 1.0$ \\
\hline \multirow[t]{3}{*}{ Lake water } & Added $\left(\mu \mathrm{g} \mathrm{L}^{-1}\right)$ & 0 & 19.5 & Added $\left(\mu \mathrm{g} \mathrm{L}^{-1}\right)$ & 0 & 31.2 \\
\hline & Found $\left(\mu \mathrm{g} \mathrm{L}^{-1}\right)$ & $\mathrm{BDL}^{\mathrm{a}}$ & $19.7 \pm 0.3$ & Found $\left(\mu \mathrm{g} \mathrm{L}^{-1}\right)$ & $5.24 \pm 0.67$ & $31.3 \pm 0.2$ \\
\hline & Recovery (\%) & - & $100.9 \pm 1.4$ & Recovery (\%) & - & $100.3 \pm 0.7$ \\
\hline \multirow[t]{3}{*}{ River water } & Added $\left(\mu \mathrm{g} \mathrm{L}^{-1}\right)$ & 0 & 19.5 & Added $\left(\mu \mathrm{g} \mathrm{L}^{-1}\right)$ & 0 & 31.2 \\
\hline & Found $\left(\mu \mathrm{g} \mathrm{L}^{-1}\right)$ & $0.71 \pm 0.12$ & $19.6 \pm 0.2$ & Found $\left(\mu \mathrm{g} \mathrm{L}^{-1}\right)$ & $1.34 \pm 0.15$ & $30.8 \pm 0.2$ \\
\hline & Recovery (\%) & - & $100.3 \pm 0.9$ & Recovery (\%) & - & $98.7 \pm 0.7$ \\
\hline
\end{tabular}

a 'BDL' - Below Detectable Limit 


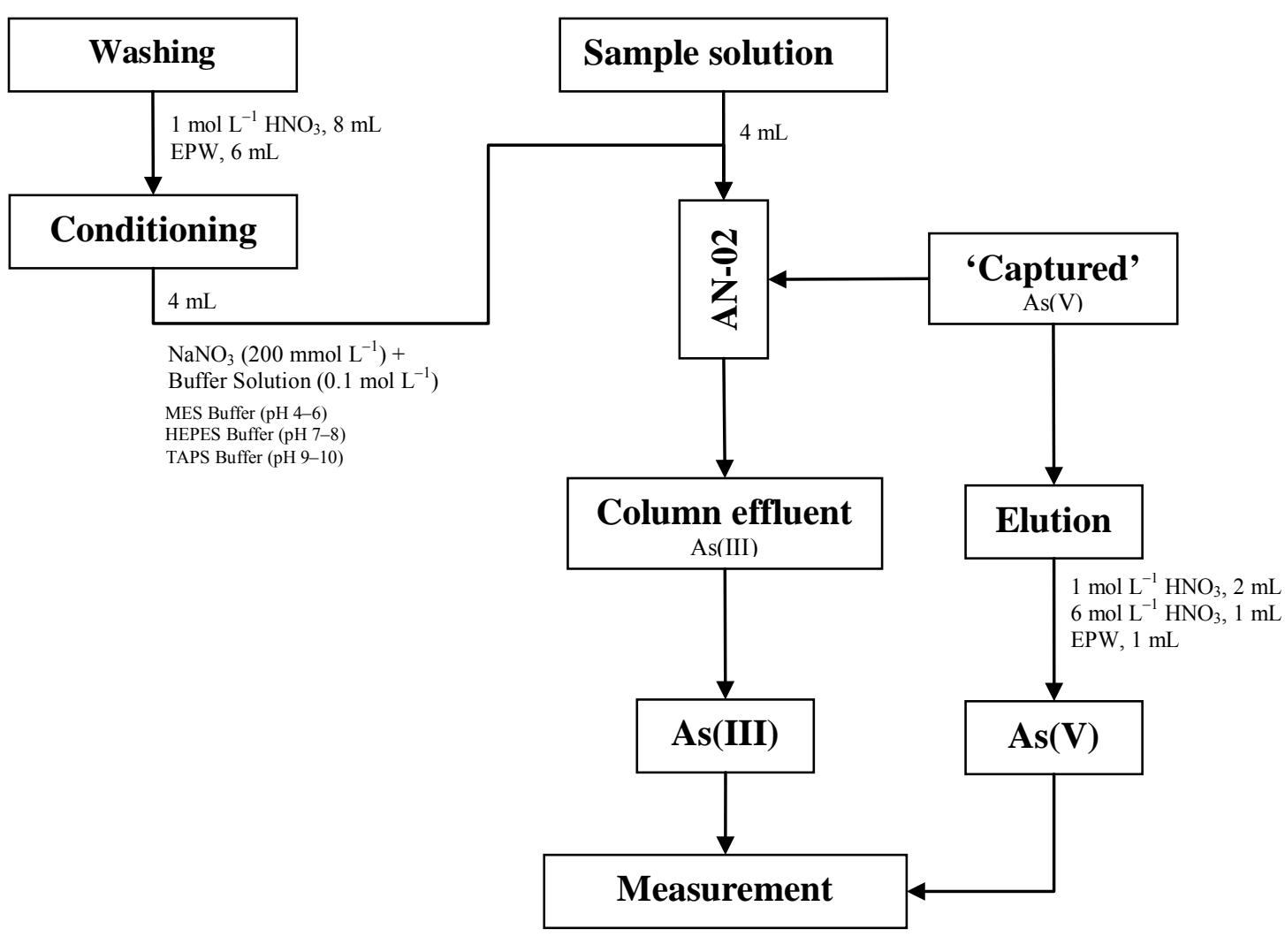

GF-AAS, PerkinElmer, AAnalyst 600

Fig. 1. Schematic diagram of the experimental setup 

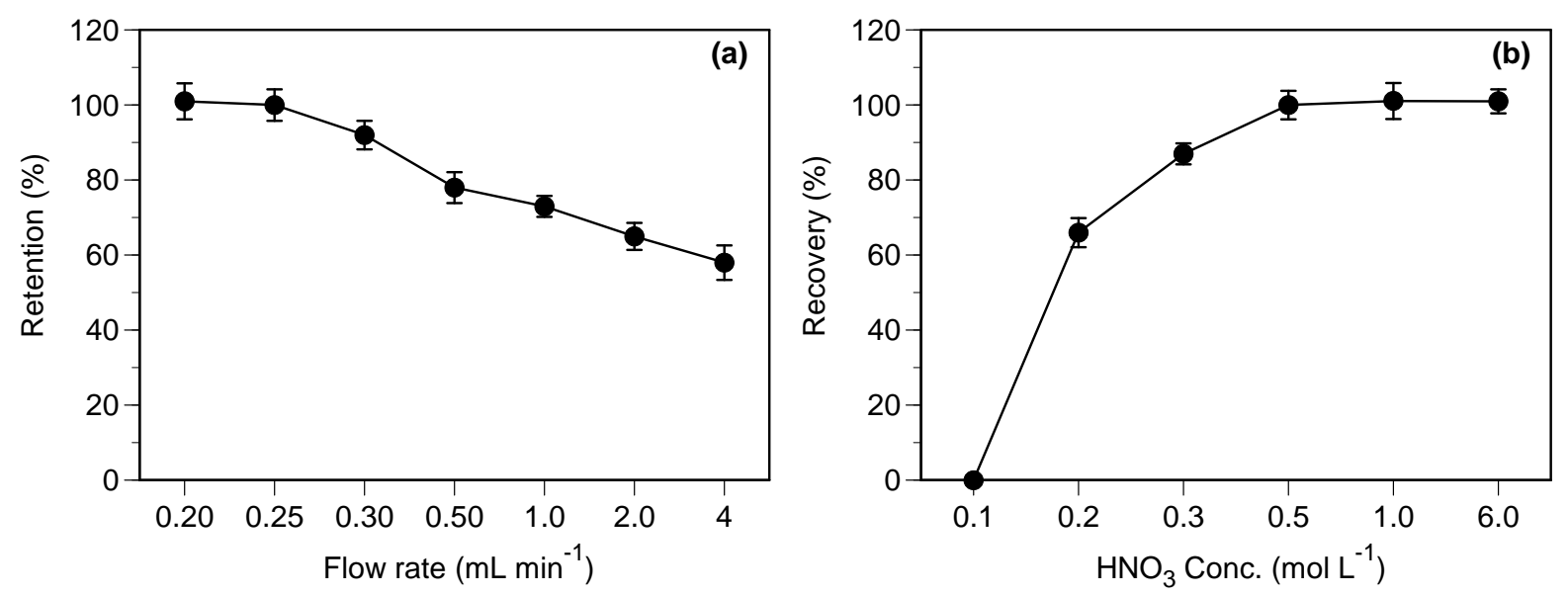

Fig. 2. Effect of (a) sample loading flow rate and (b) eluent concentration on the separation performance of the AN-02 MRT-SPE system. Sample solution-As(V) (100 $\left.\mu \mathrm{mol} \mathrm{L}^{-1}\right)$, matrix $-\mathrm{H}_{2} \mathrm{O}, \mathrm{pH}-7$, sample volume-4 $\mathrm{mL}$, loading flow rate-(a) 0.2 to $2 \mathrm{~mL} \mathrm{~min}^{-1}$ (b) 0.2 $\mathrm{mL} \mathrm{min}{ }^{-1}$, elution-(a) $1 \mathrm{~mol} \mathrm{~L}^{-1} \mathrm{HNO}_{3}(2 \mathrm{~mL})+6 \mathrm{~mol} \mathrm{~L}{ }^{-1} \mathrm{HNO}_{3}(1 \mathrm{~mL})+\mathrm{EPW}(1 \mathrm{~mL})(\mathrm{b})$ 0.1 to $6 \mathrm{~mol} \mathrm{~L}^{-1} \mathrm{HNO}_{3}(4 \mathrm{~mL})(n=3)$ 

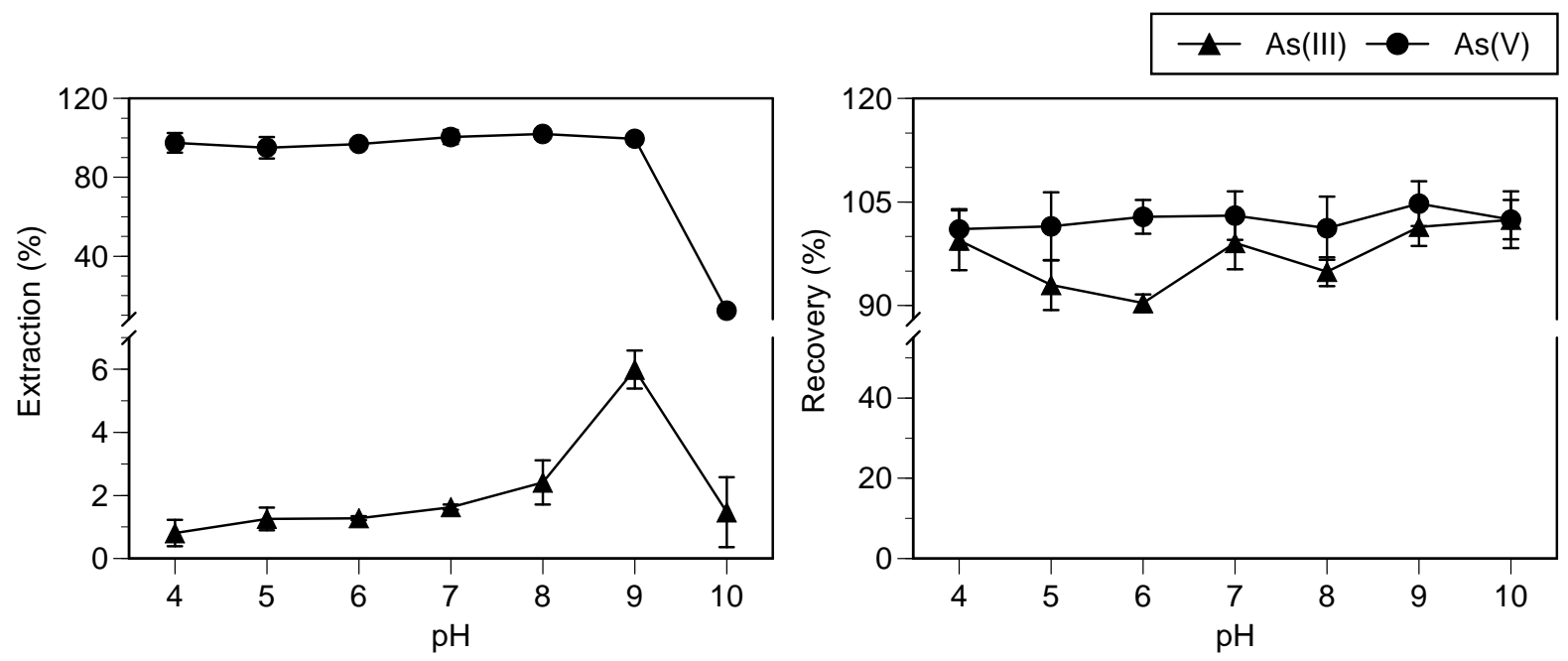

Fig. 3. The behavior of the AN-02 MRT-SPE system for the separation of tri- and pentavalent arsenic species. Sample solution-As(III) and $\operatorname{As}(V)\left(100 \mu \mathrm{mol} \mathrm{L}{ }^{-1}\right)$, matrix$\mathrm{H}_{2} \mathrm{O}, \mathrm{pH}-4$ to 10 , sample volume $-4 \mathrm{~mL}$, flow rate- $0.2 \mathrm{~mL} \mathrm{~min}{ }^{-1}$, elution- $1 \mathrm{~mol} \mathrm{~L} \mathrm{LNO}_{3}(2$ $\mathrm{mL})+6 \mathrm{~mol} \mathrm{~L}^{-1} \mathrm{HNO}_{3}(1 \mathrm{~mL})+\mathrm{EPW}(1 \mathrm{~mL})(n=3)$ 


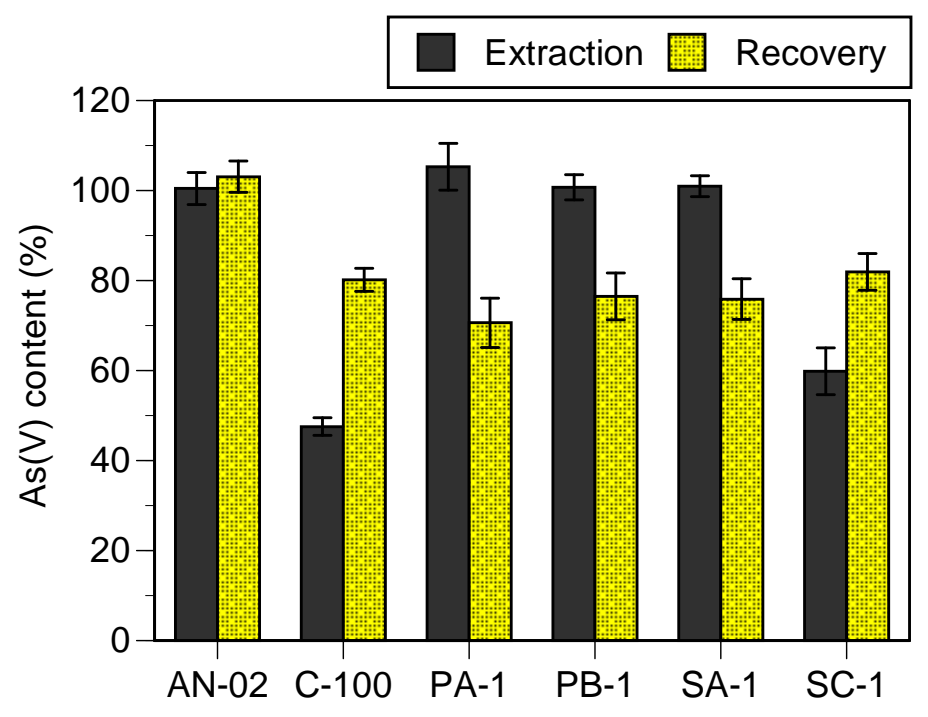

Fig. 4. Comparative separation performance of different SPE systems (AN-02: AnaLig AN02, C-100: Chelex-100, PA-1: NOBIAS Chelate PA-1, PB-1: NOBIAS Chelate PB-1, SA-1: NOBIAS Ion SA-1, SC-1: NOBIAS Ion SC-1). Sample solution-As(V) $\left(100 \mu \mathrm{mol} \mathrm{L}^{-1}\right)$, matrix $-\mathrm{H}_{2} \mathrm{O}, \mathrm{pH}-7$, sample volume- $4 \mathrm{~mL}$, flow rate- $-0.2 \mathrm{~mL} \mathrm{~min}{ }^{-1}$, elution- $1 \mathrm{~mol} \mathrm{~L}^{-1} \mathrm{HNO}_{3}$ $(2 \mathrm{~mL})+6 \mathrm{~mol} \mathrm{~L}^{-1} \mathrm{HNO}_{3}(1 \mathrm{~mL})+\mathrm{EPW}(1 \mathrm{~mL})(n=3)$ 